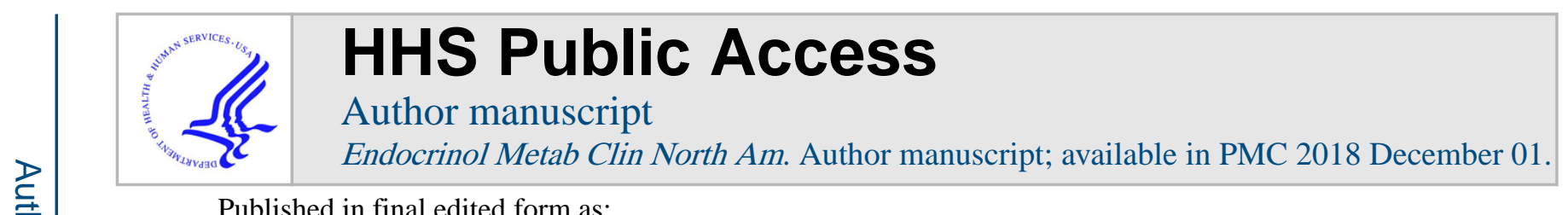

Published in final edited form as:

Endocrinol Metab Clin North Am. 2017 December ; 46(4): 1039-1059. doi:10.1016/j.ecl.2017.07.009.

\title{
Role of Vitamin D in Cardiovascular Diseases
}

\author{
Vikrant Rai and Devendra K. Agrawal ${ }^{\star}$ \\ Department of Clinical and Translational Science, Creighton University School of Medicine, \\ Omaha, NE 68178
}

\begin{abstract}
Vitamin D is critical in mineral homeostasis and skeletal health, and plays regulatory role in nonskeletal tissues. Vitamin D deficiency is associated with chronic inflammatory diseases, including diabetes and obesity both being strong risk factors for cardiovascular diseases (CVD). CVD, including coronary artery disease, myocardial infarction, hypertrophy, cardiomyopathy, cardiac fibrosis, heart failure, aneurysm, peripheral arterial disease, hypertension, and atherosclerosis, are major causes of morbidity and mortality worldwide. The association of these diseases with vitamin D deficiency and improvement with vitamin D supplementation suggest its therapeutic benefit. Here, we critically review the recent findings on the association of vitamin D deficiency and CVD.
\end{abstract}

\section{Keywords}

Vitamin D deficiency; Cardiovascular disease; Myocardial infarction; Left ventricular hypertrophy; Cardiomyopathy; Cardiac failure and fibrosis; Atherosclerosis; Peripheral vascular disease

\section{Introduction}

Vitamin D is a fat-soluble vitamin that also functions as a steroid hormone. Other than the dietary sources, vitamin $\mathrm{D}$ is produced non-enzymatically under the skin on exposure to ultraviolet sunlight and metabolized in liver and kidney involving cytochrome P450 enzymes (CYP2R1, CYP27B1, CYP24A1, CYP27B1) [1] (Figure 1). Vitamin D plays a crucial role in mineral homeostasis and skeletal health. As a steroid hormone and immunomodulator, vitamin $\mathrm{D}$ regulates the immune response of the body. Deficiency of vitamin $\mathrm{D}$ has been associated with diseases such as rickets, osteomalacia, osteoporosis, skin diseases and cardiovascular diseases (CVD) [1-3]. Currently, vitamin D deficiency exceeding 50\%

\footnotetext{
*Corresponding author: Devendra K. Agrawal, Ph.D. (Biochem), Ph.D. (Med. Sciences), MBA, MS (ITM), FAAAAI, FAHA, FAPS, FIACS, Professor and Chairman, Department of Clinical \& Translational Science, The Peekie Nash Carpenter Endowed Chair in Medicine, Creighton University School of Medicine, CRISS II Room 510, 2500 California Plaza, Omaha, NE, 68178, USA, Tel: (402) 280-2938, Fax: (402) 280-1421, dkagr@creighton.edu.

Vikrant Rai, M. B. B. S., M.S., Department of Clinical \& Translational Science, Creighton University School of Medicine, CRISS II Room 510, 2500 California Plaza, Omaha, NE, 68178, USA, vikrantrai@creighton.edu

Disclosure: The authors have nothing to disclose.

Publisher's Disclaimer: This is a PDF file of an unedited manuscript that has been accepted for publication. As a service to our customers we are providing this early version of the manuscript. The manuscript will undergo copyediting, typesetting, and review of the resulting proof before it is published in its final citable form. Please note that during the production process errors may be discovered which could affect the content, and all legal disclaimers that apply to the journal pertain.
} 
worldwide [4] warrants further investigations to explore the role of vitamin D in CVD and other diseases.

Vitamin D deficiency is associated with inflammation in the metabolic syndrome, a risk factor for CVD. Low levels of vitamin D have been associated with increased risk of CVD such as coronary artery disease (CAD) [5], myocardial infarction (MI) [6-7], hypertrophy [8], cardiomyopathy [9-10], fibrosis [11-12], heart failure (HF) [13-14]. In addition, deficiency of vitamin D has been found in arterial diseases, including aneurysm [15-16], peripheral arterial disease (PAD) [17-19], arterial calcification [20], hypertension (HTN) [21-22] and atherosclerosis [23] (Figures 2 and 3). The low levels of vitamin D in these studies may be due to different confounding factors such as environment, age, sex, socioeconomic status, and nutritional status. Daraghmeh et al. [24] conducted an NHANES III follow-up study on extended mortality and found that low vitamin D levels are inversely associated with CAD and all-cause mortality adjusting for multiple confounders. In animals, Assalin et al. [25] studied the effect of vitamin D deficiency on cardiac metabolism, morphology, and function using male weanling Wistar rats. These investigators found a significant association between vitamin D deficiency and cardiac inflammation, oxidative stress, energetic metabolic changes, cardiac hypertrophy, alterations in the left auricle and left ventricle of the heart, with fibrosis and apoptosis, and systolic dysfunction [25]. These findings were associated with increased secretion of cytokines, including tumor necrosis factor-alpha (TNF- $a$ ) and interferon-gamma (IFN- $\gamma$ ). These reports suggest an important role of vitamin D deficiency in the pathogenesis of CVD and hence vitamin D supplementation might be beneficial.

The association between vitamin D deficiency and CVD, the mechanistic basis of low vitamin $\mathrm{D}$ and CVD, autocrine and paracrine effects of vitamin $\mathrm{D}$, the effect of the reninangiotensin-aldosterone system (RAAS) have been discussed previously [3, 26]. However, due to various confounding factors, there are discrepancies in studies on the low vitamin D and CVD association. Further, Aleksova et al. [27] found a U-shaped curve between levels of vitamin D and myocardial infarction, suggesting the association of both low and high levels of vitamin D and CVD. Therefore, further understanding and research studies are needed. In this article, we have critically reviewed the recent literature on the association of vitamin D levels with cardiac and vascular diseases and the potential therapeutic role of vitamin D.

\section{Cardiac diseases}

\subsection{Cardiac hypertrophy}

Left ventricular hypertrophy (LVH) and myocardial performance have an association with low levels of vitamin D [8]. Ameri et al. [28] in a vitamin D-deficient population-based study found a significant association between HTN, vitamin D levels and LVH, with the most favorable LV geometry at intermediate vitamin D levels. Further, LVH and cardiomyopathy in Fabry's disease have been attributed to vitamin D deficiency due to less exposure to sunlight [29]. Diabetes, a chronic inflammatory disease, is a risk factor for LVH [30]. Reversal of LVH in diabetic rats [31] and attenuation of TNF-a expression by inhibition of nuclear factor-kappa beta (NF- $\mathrm{kB} / \mathrm{p} 65)$ signaling in hypertrophied rat hearts 
with vitamin D [32] suggest the role of vitamin D in reversal of LVH. These studies suggest a pathogenic role of vitamin D deficiency in LVH and vitamin D supplementation is cardioprotective. However, Pandit et al. [33] found no association of vitamin D deficiency with LVH and LV dysfunction (Figure 2). Such discrepancy could be due to the comorbidities and other confounding factors and warrants further investigation.

\subsection{Cardiomyopathy}

The pathogenesis of dilated cardiomyopathy (DCM) is usually idiopathic; however, it may arise secondary to infections or metabolic or genetic causes. Various studies have reported vitamin D deficiency-induced hypocalcemia in infants and hypoparathyroidism-induced hypocalcemia in adults as a cause for DCM and HF. Low maternal vitamin D levels were suggested as a cause for infant hypocalcemia. These studies suggest severe hypocalcemia associated with rickets in infants and hypoparathyroidism as causes of DCM, cardiac remodeling, HF, and impaired cardiac function. Improvement in clinical symptoms after vitamin $\mathrm{D}$ and calcium supplementation for the treatment of hypovitaminosis and hypocalcemia signifies the importance and protective role of vitamin $\mathrm{D}$ in cardiomyopathy [9-10, 34-39] (Table 1). Gruson et al. [40] suggested that serum $1,25(\mathrm{OH})_{2} \mathrm{D}_{3}$ and its ratio to parathyroid hormone (PTH) (1-84) strongly and independently predict cardiovascular mortality in chronic HF. Additionally, Leon Rodriguez et al. [41] suggested that vitamin D receptor (VDR) polymorphisms may also be a risk factor for increased susceptibility for cardiomyopathy and reported the increased probability of cardiac complications such as chronic Chagas cardiomyopathy with rs2228570*A VDR allele due to impaired immune response against $T$. cruzi. These studies suggest that low vitamin D levels and reduced VDR expression may be a potential risk factor for cardiomyopathy and HF (Figure 2).

Low circulating levels of vitamin D have been correlated with cardiac steatosis. Further, the whole animal VDR gene knockout $\left(\mathrm{VDR}^{-1-}\right)$ as well as the myocyte-specific VDR gene deletion are associated with impairment in cardiac structure and function. Glenn et al. [42] performed a study of VDR deficiency ( $\mathrm{VDR}^{-/}$mouse) in a murine model of cardiac steatosis expressing terminal enzyme diacylglycerol acyltransferase 1 (DGAT1) selectively in the cardiac myocyte. In this study, the mice display cardiac dysfunction, late cardiomyopathy, and HF with an increase in interstitial fibrosis and increased expression of collagen 1a1, collagen $3 a 1$, matrix metalloproteinase (MMP)-2, and osteopontin. Further, increased expression of MMPs, activated transforming growth factor-beta (TGF- $\beta$ ), epithelial-mesenchymal transition and endothelial-mesenchymal transition mediate cardiac fibrosis [43] and vitamin D attenuates expression of endothelial cell transition [44]. These results suggest an association of deficient vitamin D signaling with enhanced cardiomyopathy and an important role for vitamin D in modulating disease severity (Figure 2).

Obesity is a chronic inflammatory disease associated with low vitamin D levels. Low vitamin $\mathrm{D}$ levels associated with obesity could be due to an increase in total body clearance of vitamin $\mathrm{D}$ and increased consumption of vitamin $\mathrm{D}$ in fighting against obesity-associated inflammation [45]. Chronic inflammation in obesity is a risk factor for diabetes and together is a risk factor for cardiac diseases such as cardiomyopathies, CAD, MI, fibrosis, 
arrhythmias, and HF [46-47]. Increased expression of the myocardial receptor for advanced glycation end products (RAGE), TNF- $a$, p65 subunit of NF- $\kappa B$, a subunit of inhibitor of $\mathrm{kB}$ (I $\mathrm{KBa}$ ), subunits of NADPH oxidase (NOX4 and $\mathrm{p} 22^{\mathrm{phox}}$ ), angiotensin II type 1 receptor (AT1R), TGF- $\beta 1$, TGF- $\beta$ receptor I, total and phosphorylated SMAD2/3 and ERK, MMP2, and procollagen I and decreased expression of tissue inhibitors of metalloproteinases 2 (TIMP2) were observed in diabetic mice. Treatment of the diabetic mice with calcitriol resulted in decreased expression of myocardial RAGE, TNF- $\alpha$, p2 $2^{\text {phox }}$, AT1R, TGF- $\beta 1$, pSMAD2/3 and p-ERK signaling, and procollagen I. These results suggest the beneficial role of vitamin D in decreasing the effect of diabetes on myocardial RAGE and fibrosis by modulating the AT1R, and further signify the anti-inflammatory, anti-oxidative, and cardioprotective effects of vitamin D [48] (Figure 2).

\subsection{Myocardial infarction}

Low levels of vitamin D is associated with the status, and incident events of CVDs [7]. Analysis of 478 subjects diagnosed with acute MI showed a high prevalence of vitamin D deficiency in all seasons, though lower in summer than winter [6]. Low plasma vitamin D levels are independently associated with poor outcomes in the hospital and 1-year follow-up in the acute coronary syndrome (ACS) [49] and acute MI patients [50]. Further, hyperlipidemia is a risk factor for CVD and serum vitamin D has an inverse association with the levels of total cholesterol, low-density lipoprotein (LDL), homocysteine, triglycerides, and a positive association with high-density lipoprotein (HDL). Since hyperlipidemia is a risk factor for CVD and vitamin D has an inverse relationship with these lipid levels, vitamin D supplementation might be protective against CVD [51].

Atherosclerosis and the formation of thrombus and embolus are major risk factors for MI. Inflammation plays a major role in the pathogenesis of these risk factors as well as in postmyocardial remodeling. Further, vitamin D deficiency is associated with increased inflammation, pro-inflammatory cytokines, and atherosclerosis, and vitamin D supplementation may reduce these factors [52-53]. Thus, vitamin D deficiency may play a role in MI. It is further supported by a high prevalence of vitamin D deficiency in acute MI patients [54-55]. However, studies have reported no association between vitamin D levels, inflammatory markers, and patients with ACS [56-57]. These results suggest the need of further research to elucidate the role of vitamin $\mathrm{D}$ in the pathogenesis of atherosclerosis and MI (Figure 2).

Polymorphisms or genetic variations of the VDR gene (eg. rs7968585) could be a positive predictor for MI [58]. Further, the upregulation of endogenous VDR expression in the mouse heart after the myocardial ischemia/reperfusion by natural and synthetic agonists and reduction in the myocardial infarct size with improved cardiac function suggest the protective role of upregulated VDR. The cardioprotective effect of VDR activation is attributed to inhibited endoplasmic reticulum stress, attenuated mitochondrial impairment, decreased autophagy dysfunction, and reduced cardiomyocyte apoptosis [59]. Further, reduced expression of myocardial vitamin D receptors in obstructive nephropathy rats is related to the myocardial remodeling with fibrosis with an increase in arrhythmogenesis. 
Protection against these changes by restoring myocardial vitamin $\mathrm{D}$ receptor levels with paricalcitol suggests the protective role of vitamin $\mathrm{D}$ [60].

\subsection{Cardiac fibrosis and remodeling}

Diabetes is a risk factor for cardiac diseases including cardiac fibrosis. Increased expression of connective tissue growth factor (CTGF), TGF- $\beta 1$, SMAD3, poly [ADP-ribose] polymerase 1 (PARP1), sirtuin 1 (SIRT1), and mechanistic target of rapamycin (mTOR) in diabetes mediate cardiac fibrosis [61-63]. The negative regulation of the activity of TGF- $\beta 1$, SMAD3, CTGF, and PARP1/SIRT1/mTOR pathway with vitamin D suggests the protective role of vitamin D on fibrosis [63-66](Table 1). Wang et al. [67] using the rat model reported that diabetes induces the cardiac weight index, plasma glucose, lactic dehydrogenase and creatine kinase with the reduced body and cardiac weights and pathological changes of fibrosis. Further, reduction of these parameters and minimal pathological changes with supplementation with vitamin D suggest the beneficial role of vitamin D in cardiac fibrosis. Furthermore, inflammation plays a major role in post-infarction remodeling [68], and vitamin D being an anti-inflammatory agent may play a crucial role [69] (Figure 2).

Since vitamin D deficiency is associated with the development of cardiac hypertrophy and fibrosis, genomics of VDR may also play a role in the development of cardiac fibrosis. Dorsch et al. [12] suggested that the biomarker for collagen type III synthesis, PIIINP, is associated with the CGA haplotype of BsmI, ApaI, and TaqI single nucleotide polymorphisms in the VDR. Further, decreased cardiac fibrosis [11] and attenuated cardiac remodeling and dysfunction in polycystic ovarian syndrome [70] with vitamin D supplementation and/or VDR activation suggest the role of vitamin $\mathrm{D}$ in treating cardiac fibrosis [71]. Furthermore, the cardioprotective effects of VDR activators and modulators suggest the potential therapeutic role of vitamin D [72-73].

\subsection{Heart failure}

Vitamin D deficiency is associated with MI, post-MI HF as well as with new onset HF [74]. Bae et al. [13] suggested that vitamin D deficiency after MI in VDR knockout mice leads to decreased survival rate and cardiac function, and vitamin $\mathrm{D}$ signaling promotes cardioprotection through anti-inflammatory, anti-apoptotic and anti-fibrotic mechanisms. Further, vitamin D deficiency is associated with increased inflammation and inflammatory cytokines such as TNF- $a$, interleukin (IL)-6, and interleukin-1beta (IL-1 $\beta$ ) involved in mediating the cardiac diseases and HF [14]. Vitamin D supplementation reduces these cytokines in chronic HF [75]. IL-33 is a member of the IL-1 family of cytokines. IL-33 through its receptor ST2 prevents cardiomyocyte apoptosis and improves cardiac function and survival after MI [76] (Figure 2). An increase in the circulating levels of the soluble decoy receptor of ST2 (sST2) is associated with cardiac remodeling, fibrosis and HF [77]. Further, low levels of vitamin D and hypoparathyroidism are associated with cardiomyopathy remodeling and worsening of HF [78]. Furthermore, calcitriol, the biologically active form of vitamin $\mathrm{D}$, regulates cardiac function and might modulate ST2 [79]. Thus, interrelations of the vitamin D/PTH axis and sST2 regulating inflammation and fibrosis in the heart may also regulate the HF. Studies have suggested the strong relationship between low vitamin D levels, sST2 and the vitamin D/PTH (1-84) axis and HF. It was 
proposed that sST2 levels and a low plasma $1,25(\mathrm{OH})_{2} \mathrm{D}_{3} / \mathrm{PTH}(1-84)$ ratio are strong predictors of worsening HF, hospitalization, reduced survival, and mortality due to cardiac disease [80-83]. However, there was no association between plasma levels of calcidiol, calcitriol, or PTH and risk of developing HF [74].

Further, as discussed earlier, vitamin D deficiency associates with HF, and vitamin D supplementation may be beneficial [84]. However, there are reports of no improvement or beneficial effect of vitamin D in HF with vitamin D supplementation, and the discrepancies between the studies may be due to the genetic variations in the VDR (eg. Fok1) gene [8589]. Improvement and beneficial effects of vitamin D on LV structure and function in the VINDICATE (VitamIN D treatIng patients with Chronic heArT failurE) study in HF [90] and decreased renin activity with short-term vitamin D supplementation in chronic HF patients [91] suggest the therapeutic role of vitamin D (Table 1).

\subsection{Rhythm abnormalities}

Vitamin D deficiency is associated with CVD including cardiac fibrosis which is a hallmark for the arrhythmias. Low vitamin D levels are associated with HF and atrial fibrillations (AF) in HF patients [92]. Low levels of vitamin D are significantly associated with more extensive left atrial fibrosis in patients with lone paroxysmal AF as well as with recurrence of AF after cryoablation [93] and post coronary-artery bypass graft surgery [94]. These results suggest that low vitamin D levels are associated with increased incidence of AF. Increased inflammation, oxidative stress and activation of renin-angiotensin system (RAS) may cause increased arrhythmic events in HF. Furthermore, anti-inflammatory and antioxidative properties of vitamin $\mathrm{D}$, its binding to VDR on myocyte along with negative regulation of RAS mediate the amelioration of inflammation and pro-arrhythmic substrate formation leading to decreased chances of fibrillation. These findings suggest the protective role of vitamin D [95] (Figure 2). However, no independent association was found between low vitamin D levels and AF after coronary artery bypass surgery [96]. Similarly, the Atherosclerosis Risk in Communities (ARIC) study did not find any significant association between low levels of vitamin $\mathrm{D}$ and incident $\mathrm{AF}$ in a community-based cohort and in a meta-analysis of prospective studies comprising 12,303 subjects. However, the authors recommended further studies for an association in the younger patient [97].

\section{Vascular disease}

\subsection{Atherosclerosis}

Obesity is a major risk factor for CVD. In human subjects, there is a known association between vitamin D deficiency and hypertension (HTN), metabolic syndrome and related risk factors of CVD. Perivascular adipose tissue (PVAT) in obesity produces factors that affect atherogenesis and smooth muscle cell proliferation, thereby affecting the contractile function. Pelham et al. [98] demonstrated an association between vitamin D deficiency, impaired normal ability of PVAT to suppress contractile responses of the underlying mesenteric resistance artery to angiotensin II and serotonin, and enhanced angiotensin IIinduced vasoconstriction. Vitamin D deficiency was also associated with the increased expression of TNF- $a$ and heat-induced factor-1 alpha (HIF-1a). These results suggest the 
protective role of vitamin $\mathrm{D}$ through regulating the mediators of inflammation and hypoxia signaling against vascular dysfunction, hypertension and CVD. Lin et al.[99] reported similar effects of VDR agonists and retinoid $\mathrm{X}$ receptor agonists in alleviating atherosclerosis through inhibition of oxidative stress in diabetic mice model (Figure 3). An inverse correlation between the vitamin D level and the stage of coronary atherosclerosis along with the levels of total cholesterol, LDL and triglycerides in women and men over 70 years has been reported [100]. Similarly, low levels of vitamin D have been associated with subclinical atherosclerosis, increased expression of high-sensitivity cardiac troponin $\mathrm{T}$ and $\mathrm{N}$-terminal pro-brain natriuretic peptide (markers of subclinical myocardial damage and wall stress) [101]. In addition, the role of vitamin D binding protein (VDBP) and its polymorphism in relation to atherosclerosis and the role of VDBP in resistance to atherosclerosis leading to the longevity of patients have also been examined [102]. However, no significant association between the serum vitamin $\mathrm{D}$ level and carotid atherosclerosis in patients with chronic kidney disease patients found by $\mathrm{Ng}$ et al. [103] indicate the need for further research.

Inflammation plays a crucial role in the pathogenesis of plaque development and progression involving mediators such as triggering receptor expressed on myeloid cells 1 (TREM-1), toll-like receptor 4 (TLR4), and cytokines such as IL-6, TNF-a, IL-1 $\beta$, and IFN- $\gamma$, and macrophages [104-105] (Figure 3). Low intraplaque VDR expression, the prevalence of VDR expression in M1 compared to M2 macrophages, and increased VDR expression in M1 macrophages incubated with $1,25(\mathrm{OH})_{2} \mathrm{D}_{3}$ with suppression of TLR4 expression suggest that low intraplaque VDR expression predicts an adverse cardiovascular event in patients with carotid stenosis. These findings signify the possible important therapeutic role for vitamin D and VDR in the treatment of arterial plaque [106]. Further, the protective role of vitamin $\mathrm{D}$ in atherosclerosis via regulation of macrophage polarization and cholesterol efflux, and reducing intimal hyperplasia and restenosis has been documented in a swine model $[52,107]$. Vitamin D has a protective effect on the endothelial cells by reducing endoplasmic reticulum stress and oxidative stress thereby reducing the risk of atherosclerosis [108]. Furthermore, significant inhibition of atherosclerosis in ApoEdeficient mice with intravenous transfusion of endothelial progenitor cells with overexpressed VDR suggests the role of vitamin D and VDR in this disorder and a potential method for angiogenic therapy [109].

\subsection{Arterial calcification}

Subclinical atherosclerosis is precipitated by calcification of the arteries. A significant positive association between the low levels of vitamin $\mathrm{D}$ and coronary artery calcification has been reported by a population-based cross-sectional study [110]. Increased calcification and higher expression of osteogenic key factors such as Msx2, Bmp2, and Runx2 in VDR knockout $\left(\mathrm{VDR}^{-/}\right)$mice as well as in LDL receptor knockout $\left(\mathrm{LDLr}^{--}\right)$mice fed on western diet with low vitamin D $(50 \mathrm{IU} / \mathrm{kg})$ suggest the role of VDR and vitamin D deficiency as risk factors for aortic valve and aortic vessel calcification [20]. 


\subsection{Occlusive arterial disease}

Arterial thrombosis is a major cause of anginal episodes, and rupture of the thrombus results in embolus formation leading to MI. Coronary occlusion precipitates MI, and coronary collaterals circulation (CCC) protects the myocardium from acute events in cases of the total coronary occlusive disease. Dogan et al. [111] found low vitamin D levels as the strong predictor of and associated with poor CCC. Further, increased expression of the vascular smooth muscle cell (VSMC)-derived tissue factor (TF) plays an important role in thrombus formation involving TNF- $\alpha$ and NF- $\kappa$ B. Phosphorylation of NF- $\kappa B$ is accompanied by upregulation of TF signalling because of increased expression of protease-activated receptor-2 (PAR-2) and down-regulation of VDR (Figure 3). This results in increased inflammation and progression of thrombus formation. Attenuation in the expression of PAR-2, TNF- $a$, and NF- $\kappa B$ with vitamin D suggests the beneficial role of vitamin D in thrombosis [112]. Further, the significant reduction in the anginal episodes and reduction in the use of sublingual nitrates with vitamin D supplementation suggest the beneficial role of vitamin D in CVD [113](Table 1).

\subsection{Aneurysm and peripheral arterial disease}

Vitamin D deficiency plays a role in the pathogenesis of vascular disease atherosclerosis. However, the presence of VDR in the vascular endothelium and VSMCs [1] suggests that vitamin D may play a role in other vascular diseases, such as the aneurysm, peripheral arterial disease (PAD), and calcification. A study on 490 patients by van de Luijtgaarden et al. [16] suggests that vitamin D deficiency is associated with the severity of arterial diseases such as abdominal and/or thoracic aneurysm and PAD, and the underlying mechanism for these occlusive and aneurysmal diseases is different from atherosclerosis. Vitamin D deficiency is a risk factor for severity of arterial disease irrespective of the type of arterial disease and independent of traditional cardiovascular risk factors [15-16]. Similarly, the study by Wong et al. [114] with 311 patients also found the association of low vitamin D with the severity of the abdominal aortic aneurysm (AAA), and suggested a graded inverse relationship between vitamin D concentrations and AAA diameter.

Further, inflammation plays a key role in the pathogenesis of aneurysm development and vitamin D being an anti-inflammatory agent may reduce the inflammation and progression. Reduction in AAA dissection, induced by Angiotensin-II in apoE ${ }^{-/}$mice, by VDR activation with oral vitamin $D$ suggests the potential therapeutic role of vitamin $D$ to decrease the AAA progression [115]. The reduction in the progression of AAA was attributed to decrease in many parameters, including macrophage infiltration, neo-vessel formation, MMP-2 and MMP-9 activation, chemokines (CCL2, CCL5, CXCL1) expression, and extracellular signal-regulated kinases 1/2, p38 mitogen-activated protein kinase, and NF- $\kappa$ B activity (Figure 3). Furthermore, the anti-inflammatory effect of vitamin D by reducing the expression of inflammatory mediators, CD4+ T-helper cells, and cytokines IL-2, IL-4, and IL-10 with paricalcitol and reduction in the local inflammation in AAA patients suggest the therapeutic role of vitamin $\mathrm{D}$ in arterial aneurysms. The antiinflammatory action of vitamin D was suggested to be mediated by an effect on calcineurinmediated responses [116](Table 1). Further, a meta-analysis comprising six case-control studies assessing 6,418 patients with PAD suggests the association of low levels of 
circulating vitamin D with PAD and with chronic limb ischemia [17]. Li et al. [18] and Oh et al. [19] also reported similar association in their studies with 1,028 diabetic patients and 8,960 subjects, respectively. The association of low levels of vitamin D with the prevalence of PAD support the role of vitamin D deficiency as an independent risk factor for CVD.

\subsection{Hypertension}

The imbalance between the vasoconstriction and vasodilatation due to various genetic and epigenetic factors (vitamin D deficiency) results in vasoconstriction leading to essential hypertension (HTN). Chen et al. [117] reported a clinically significant antihypertensive effect of vitamin D in vitamin D-deficient essential hypertensive patients. Similarly, significantly low vitamin D levels are associated with non-dipper HTN as compared to dipper HTN [118]. Hypertensive patients with a nocturnal reduction in average daytime systolic and diastolic blood pressure of less than $10 \%$ are classed as non-dippers and of 10$20 \%$ as dippers. In addition, impaired renin-angiotensin system (RAS) is a risk factor for HTN and low vitamin D levels are associated with impaired RAS. Negative regulation of RAS with vitamin D supplementation suggests the beneficial role of vitamin D in the treatment of HTN [95]. Aortic stiffness, decreased vessel compliance, and atherosclerosis are associated with HTN. The association between the low circulating vitamin D levels and aortic stiffness independent of classical risk factors and inflammatory markers in prediabetic subjects suggests vitamin D deficiency as a risk factor for CVD and HTN [119]. However, Kang et al. [120] reported that the association between levels of vitamin D and blood pressure, lipid profiles, glycemic index, brachial-ankle pulse wave velocity, and carotid artery intima-media wall thickness are sex-dependent, and serum vitamin D level may not be a risk factor related to subclinical atherosclerosis and arterial stiffness.

Vitamin D regulates the proliferation of endothelial cells (EC) and VSMCs [121] and VDR is present in these cells [1]. Endothelial dysfunction plays a key role in vascular diseases such as HTN. Vitamin D deficiency affecting the EC may precipitate HTN [22] (Figure 3). Significant impairment in the acetylcholine-induced aortic relaxation, increased sensitivity to the hypertensive effects of angiotensin II, and increased expression of angiotensin II infusion-induced hypertrophy-sensitive myocardial genes in endothelial-specific VDR knockout mice compared to control mice suggest the potential role of endothelial VDR in EC function and blood pressure control and the therapeutic role of VDR agonists in the management of EC dysfunction-related CVD [21].

\section{Future directions}

Studying the microbiota for disease pathogenesis is an emerging field of research. Studies have hypothesized that a change in the microbiota results in an immune response and may result in a pro-inflammatory environment [122-123]. Altered intestinal microbiome due to vitamin D deficiency also impairs the B vitamins due to altered intestinal bacteria. This may result in an increased risk of atherosclerosis, HTN, tachycardia, atrial arrhythmias, and a "hyper-adrenergic" state predisposing to heart disease and stroke-mediated by a proinflammatory state and lack of pantothenic acid. Improvement of the intestinal microbiota with the vitamin D supplementation along with B vitamins support the therapeutic benefit of 
vitamin D [124]. Thus, studying the intestinal and plaque microbiome might elucidate the novel therapeutic options for CVD.

The $1,25(\mathrm{OH})_{2} \mathrm{D}_{3} / \mathrm{PTH}$ ratio plays an important role in CVD. Further, PTH, fibroblast growth factor23 (FGF23) and 25(OH)D itself regulate the enzymes involved in the calcitriol synthesis. FGF23 negatively regulates the PTH. PTH have a positive and FGF23 have a negative effect on CYP27B1. The $1,25(\mathrm{OH})_{2} \mathrm{D}_{3}$ have a feedback inhibitory effect on CYP27B1 [125] (Figure 1). FGF23 also regulates vitamin D metabolism by regulating the urinary secretion of phosphate in the presence of FGF receptor 1 and its co-receptor Klotho [126]. Increased FGF23 along with increased PTH in kidney disease increase the cardiovascular events and mortality, and calcium supplementation reduces FGF23, CVD events, and mortality [127]. Increased levels of FGF23 decrease serum $1,25(\mathrm{OH})_{2} \mathrm{D}_{3}$ without any change in PTH and anti-aging protein Klotho post-MI in a mouse model [128]. Increased FGF23 is also associated with incident AF, LVH, and systolic and diastolic dysfunction [129]. Furthermore, inactive Klotho is associated with increased atherosclerosis, vascular calcification and CVD events. Whereas, the activation of klotho is associated with decreased atherosclerosis, and vascular calcification [126]. Furthermore, soluble a-Klotho has a cardioprotective effect via inhibition of TRPC6 channel-mediated abnormal $\mathrm{Ca}^{2+}$ signalling in the heart [130], and higher PTH levels are associated with LVH and increased risk of incident HF [131]. These results suggest that interactions between PTH, FGF23, klotho, calcium, and vitamin D levels play a crucial role in the pathogenesis of CVD. Thus, supplementation of vitamin D and calcium might be cardioprotective. However, Kopecky et al. [132] suggested lack of evidence between calcium with or without vitamin D intake from food or supplements and the risk for CVD mortality, or all-cause mortality in generally healthy adults. Thus, interactions between PTH, FGF23, klotho, calcium levels, vitamin D levels, and the underlying signalling mechanism need further research.

Further, renin-angiotensin system (RAS) and AT1R play important roles in the pathogenesis of CVD. ACE inhibitors and ARB (angiotensin II receptor blockers) are used to treat HTN, and they act differently on RAS [133]. ACE inhibitors block both AT1R and angiotensin II type 2 receptors (AT2R) while ARB blocks only AT1R. Thus, ARB therapy results in a decrease in blood pressure as well as an overexpressed AT2R [133]. Though the beneficial effect of AT1R is well established in treating HTN, HF, atherosclerosis, and aortic aneurysms, the beneficial effect of AT2R is under investigation [133-134]. The beneficial role of the AT2R agonist, Compound 21, in diabetes-associated atherosclerosis [135] and increased AT2R expression by targeting intron 2 enhancer element to increase satellite cell proliferation and potentiating skeletal muscle regenerative capacity in CHF patient has been discussed [136]. However, the protective role of AT2R, the underlying mechanism and interaction with vitamin D levels in CVD warrant further investigation.

\section{Conclusion}

CAD, stroke, and sudden cardiac death remain the leading cause of morbidity and mortality worldwide. For screening, the assessment of the at-risk individuals is based on Framingham Risk Score or AHA/ACC Pooled Cohort Equations/guidelines. However, scoring the risk with traditional risk factors using these methods may underestimate or overestimate the risk. 
Thus, the need to consider the inclusion of additional factors associated with the CVD disease to decrease the morbidity and mortality and improve the outcome has been warranted [137-138]. Further, reduced level of C-reactive protein levels in 2 clinical trials $[139,140]$, relaxation of VSMCs, decreased renin production by kidney, and reduced mortality in renal failure patients with $1,25(\mathrm{OH})_{2} \mathrm{D}_{3}$ [141] suggest the protective role of vitamin D. Since, the above-discussed studies suggest strong evidence for the role of vitamin D deficiency in the pathogenesis of CVD, inclusion of low levels of vitamin D in the risk stratification may be beneficial in identifying the high-risk individuals and can help in guiding personalized risk assessment. Although, as discussed the interaction between PTH, FGF23, klotho, calcium, and serum 25(OH)D levels are associated with CVD. Vitamin D deficiency may serve as a novel marker and predictor of severity of CVD. However, the beneficial role of vitamin D supplementation in the CVD remains inconclusive and need further research.

\section{Acknowledgments}

This work was supported by research grants R01 HL112597, R01 HL116042, and R01 HL120659 to DK Agrawal from the National Heart, Lung and Blood Institute, National Institutes of Health, USA. The content of this review article is solely the responsibility of the authors and does not necessarily represent the official views of the National Institutes of Health.

\section{References}

1. Holick MF. Vitamin D deficiency. N Engl J Med. 2007; 357(3):266-81. [PubMed: 17634462]

2. Wadhwa B, Relhan V, Goel K, Kochhar AM, Garg VK. Vitamin D and skin diseases: A review. Indian J Dermatol Venereol Leprol. 2015; 81(4):344-55. [PubMed: 26144849]

3. Norman PE, Powell JT. Vitamin D and cardiovascular disease. Circ Res. 2014; 114(2):379-93. [PubMed: 24436433]

4. Durup D, Jorgensen HL, Christensen J, Schwarz P, Heegaard AM, Lind B. A reverse J-shaped association of all-cause mortality with serum 25-hydroxyvitamin D in general practice: the CopD study. J Clin Endocrinol Metab. 2012; 97(8):2644-52. [PubMed: 22573406]

5. Chen S, Swier VJ, Boosani CS, Radwan MM, Agrawal DK. Vitamin D Deficiency Accelerates Coronary Artery Disease Progression in Swine. Arterioscler Thromb Vasc Biol. 2016; 36(8):16519. [PubMed: 27255724]

6. Aleksova A, Belfiore R, Carriere C, Kassem S, La Carrubba S, Barbati G, et al. Vitamin D Deficiency in Patients with Acute Myocardial Infarction: An Italian Single-Center Study. Int J Vitam Nutr Res. 2015; 85(1-2):23-30. [PubMed: 26780274]

7. Anderson JL, May HT, Horne BD, Bair TL, Hall NL, Carlquist JF, et al. Relation of vitamin D deficiency to cardiovascular risk factors, disease status, and incident events in a general healthcare population. Am J Cardiol. 2010; 106(7):963-8. [PubMed: 20854958]

8. Seker T, Gur M, Ucar H, Turkoglu C, Baykan AO, Ozaltun B, et al. Lower serum 25hydroxyvitamin $\mathrm{D}$ level is associated with impaired myocardial performance and left ventricle hypertrophy in newly diagnosed hypertensive patients. Anatol J Cardiol. 2015; 15(9):744-50. [PubMed: 25592096]

9. Yilmaz O, Olgun H, Ciftel M, Kilic O, Kartal I, Iskenderoglu NY, et al. Dilated cardiomyopathy secondary to rickets-related hypocalcaemia: eight case reports and a review of the literature. Cardiol Young. 2015; 25(2):261-6. [PubMed: 24345686]

10. Polat V, Bozcali E, Uygun T, Opan S, Karakaya O. Low vitamin D status associated with dilated cardiomyopathy. Int J Clin Exp Med. 2015; 8(1):1356-62. [PubMed: 25785137]

11. Charytan DM, Padera RF, Helfand AM, Zeisberg EM. Association of activated vitamin D use with myocardial fibrosis and capillary supply: results of an autopsy study. Ren Fail. 2015; 37(6):10679. [PubMed: 25955707] 
12. Dorsch MP, Nemerovski CW, Ellingrod VL, Cowger JA, Dyke DB, Koelling TM, et al. Vitamin D receptor genetics on extracellular matrix biomarkers and hemodynamics in systolic heart failure. $\mathrm{J}$ Cardiovasc Pharmacol Ther. 2014; 19(5):439-45. [PubMed: 24500905]

13. Bae S, Singh SS, Yu H, Lee JY, Cho BR, Kang PM. Vitamin D signaling pathway plays an important role in the development of heart failure after myocardial infarction. J Appl Physiol (1985). 2013; 114(8):979-87. [PubMed: 23429874]

14. Gullestad L, Ueland T, Vinge LE, Finsen A, Yndestad A, Aukrust P. Inflammatory cytokines in heart failure: mediators and markers. Cardiology. 2012; 122(1):23-35. [PubMed: 22699305]

15. Demir M, Uyan U, Melek M. The relationship between vitamin D deficiency and thoracic aortic dilatation. Vasa. 2012; 41(6):419-24. [PubMed: 23129037]

16. van de Luijtgaarden KM, Voute MT, Hoeks SE, Bakker EJ, Chonchol M, Stolker RJ, et al. Vitamin $\mathrm{D}$ deficiency may be an independent risk factor for arterial disease. Eur J Vasc Endovasc Surg. 2012; 44(3):301-6. [PubMed: 22841360]

17. Nsengiyumva V, Fernando ME, Moxon JV, Krishna SM, Pinchbeck J, Omer SM, et al. The association of circulating 25-hydroxyvitamin D concentration with peripheral arterial disease: A meta-analysis of observational studies. Atherosclerosis. 2015; 243(2):645-51. [PubMed: 26554715]

18. Li DM, Zhang Y, Li Q, Xu XH, Ding B, Ma JH. Low 25-Hydroxyvitamin D Level Is Associated with Peripheral Arterial Disease in Type 2 Diabetes Patients. Arch Med Res. 2016; 47(1):49-54. [PubMed: 26854799]

19. Oh SH, Kweon SS, Choi JS, Rhee JA, Lee YH, Nam HS, et al. Association between Vitamin D Status and Risk of Peripheral Arterial Disease: The Dong-gu Study. Chonnam Med J. 2016; 52(3): 212-6. [PubMed: 27689032]

20. Schmidt N, Brandsch C, Kuhne H, Thiele A, Hirche F, Stangl GI. Vitamin D receptor deficiency and low vitamin D diet stimulate aortic calcification and osteogenic key factor expression in mice. PLoS One. 2012; 7(4):e35316. [PubMed: 22536373]

21. Ni W, Watts SW, Ng M, Chen S, Glenn DJ, Gardner DG. Elimination of vitamin D receptor in vascular endothelial cells alters vascular function. Hypertension. 2014; 64(6):1290-8. [PubMed: 25201890]

22. Oruc CU, Akpinar YE, Amikishiyev S, Uzum AK, Salmaslioglu A, Gurdol F, et al. Hypovitaminosis D is associated with endothelial dysfunction in patients with metabolic syndrome. Curr Vasc Pharmacol. 2016

23. Lupton JR, Faridi KF, Martin SS, Sharma S, Kulkarni K, Jones SR, et al. Deficient serum 25hydroxyvitamin D is associated with an atherogenic lipid profile: The Very Large Database of Lipids (VLDL-3) study. Journal of clinical lipidology. 2016; 10(1):72-81. e1. [PubMed: 26892123]

24. Daraghmeh AH, Bertoia ML, Al-Qadi MO, Abdulbaki AM, Roberts MB, Eaton CB. Evidence for the vitamin D hypothesis: The NHANES III extended mortality follow-up. Atherosclerosis. 2016; 255:96-101. [PubMed: 27855294]

25. Assalin HB, Rafacho BP, dos Santos PP, Ardisson LP, Roscani MG, Chiuso-Minicucci F, et al. Impact of the length of vitamin D deficiency on cardiac remodeling. Circ Heart Fail. 2013; 6(4): 809-16. [PubMed: 23709660]

26. Wang TJ. Vitamin D and Cardiovascular Disease. Annu Rev Med. 2016; 67:261-72. [PubMed: 26768241]

27. Aleksova A, Beltrami AP, Belfiore R, Barbati G, Di Nucci M, Scapol S, et al. U-shaped relationship between vitamin $\mathrm{D}$ levels and long-term outcome in large cohort of survivors of acute myocardial infarction. Int J Cardiol. 2016; 223:962-6. [PubMed: 27589046]

28. Ameri P, Canepa M, Milaneschi Y, Spallarossa P, Leoncini G, Giallauria F, et al. Relationship between vitamin D status and left ventricular geometry in a healthy population: results from the Baltimore Longitudinal Study of Aging. J Intern Med. 2013; 273(3):253-62. [PubMed: 23061475]

29. Drechsler C, Schmiedeke B, Niemann M, Schmiedeke D, Kramer J, Turkin I, et al. Potential role of vitamin D deficiency on Fabry cardiomyopathy. J Inherit Metab Dis. 2014; 37(2):289-95. [PubMed: 24141790] 
30. Somaratne JB, Whalley GA, Poppe KK, ter Bals MM, Wadams G, Pearl A, et al. Screening for left ventricular hypertrophy in patients with type 2 diabetes mellitus in the community. Cardiovasc Diabetol. 2011; 10:29. [PubMed: 21492425]

31. Fan Y, Zhang SX, Ren M, Hong LF, Yan XN. Impact of 1, 25-(OH)2D3 on Left Ventricular Hypertrophy in Type 2 Diabetic Rats. Chin Med Sci J. 2015; 30(2):114-20. [PubMed: 26149003]

32. Al-Rasheed NM, Bassiouni YA, Hasan IH, Al-Amin MA, Al-Ajmi HN, Mohamad RA. Vitamin D attenuates pro-inflammatory TNF-alpha cytokine expression by inhibiting NF-small ka, CyrillicB/p65 signaling in hypertrophied rat hearts. J Physiol Biochem. 2015; 71(2):289-99. [PubMed: 25929726]

33. Pandit A, Mookadam F, Boddu S, Aryal Pandit A, Tandar A, Chaliki H, et al. Vitamin D levels and left ventricular diastolic function. Open Heart. 2014; 1(1):e000011. [PubMed: 25332778]

34. Yilmaz O, Kilic O, Ciftel M, Hakan N. Rapid response to treatment of heart failure resulting from hypocalcemic cardiomyopathy. Pediatr Emerg Care. 2014; 30(11):822-3. [PubMed: 25373569]

35. Batra CM, Agarwal R. Hypocalcemic Cardiomyopathy and Pseudohypoparathyroidism Due to Severe Vitamin D Deficiency. J Assoc Physicians India. 2016; 64(6):74-6.

36. Laranjo S, Trigo C, Pinto FF. Dual etiology of dilated cardiomyopathy: the synergistic role of vitamin D deficiency. Rev Port Cardiol. 2014; 33(3):179e1-4. [PubMed: 24680558]

37. Bansal B, Bansal M, Bajpai P, Garewal HK. Hypocalcemic cardiomyopathy-different mechanisms in adult and pediatric cases. J Clin Endocrinol Metab. 2014; 99(8):2627-32. [PubMed: 24840807]

38. Venugopalan G, Navinath M, Pradeep B, Sobia N, Chandan Jyoti D, Nitish N, et al. Hypocalcemic Cardiomyopathy Due to Vitamin D Deficiency in a Very Old Man. J Am Geriatr Soc. 2015; 63(8): 1708-9. [PubMed: 26289698]

39. Loncar G, Bozic B, Cvetinovic N, Dungen HD, Lainscak M, von Haehling S, et al. Secondary hyperparathyroidism prevalence and prognostic role in elderly males with heart failure. $\mathrm{J}$ Endocrinol Invest. 2016

40. Gruson D, Ferracin B, Ahn SA, Zierold C, Blocki F, Hawkins DM, et al. 1,25-Dihydroxyvitamin D to PTH(1-84) Ratios Strongly Predict Cardiovascular Death in Heart Failure. PLoS One. 2015; 10(8):e0135427. [PubMed: 26308451]

41. Leon Rodriguez DA, Carmona FD, Gonzalez CI, Martin J. Evaluation of VDR gene polymorphisms in Trypanosoma cruzi infection and chronic Chagasic cardiomyopathy. Sci Rep. 2016; 6:31263. [PubMed: 27502545]

42. Glenn DJ, Cardema MC, Gardner DG. Amplification of lipotoxic cardiomyopathy in the VDR gene knockout mouse. J Steroid Biochem Mol Biol. 2016; 164:292-8. [PubMed: 26429397]

43. Rai V, Sharma P, Agrawal S, Agrawal DK. Relevance of mouse models of cardiac fibrosis and hypertrophy in cardiac research. Mol Cell Biochem. 2016

44. Lai CC, Liu CP, Cheng PW, Lu PJ, Hsiao M, Lu WH, et al. Paricalcitol Attenuates Cardiac Fibrosis and Expression of Endothelial Cell Transition Markers in Isoproterenol-Induced Cardiomyopathic Rats. Crit Care Med. 2016; 44(9):e866-74. [PubMed: 27065465]

45. Cartier JL, Kukreja SC, Barengolts E. Lower Serum 25-Hydroxyvitamin D Is Associated with Obesity but Not Common Chronic Conditions: An Observational Study of African American and Caucasian Male Veterans. Endocr Pract. 2016

46. Seferovic PM, Paulus WJ. Clinical diabetic cardiomyopathy: a two-faced disease with restrictive and dilated phenotypes. Eur Heart J. 2015; 36(27):1718-27. 1727a-1727c. [PubMed: 25888006]

47. Luft VC, Schmidt MI, Pankow JS, Couper D, Ballantyne CM, Young JH, et al. Chronic inflammation role in the obesity-diabetes association: a case-cohort study. Diabetol Metab Syndr. 2013; 5(1):31. [PubMed: 23806173]

48. Lee TW, Kao YH, Lee TI, Chang CJ, Lien GS, Chen YJ. Calcitriol modulates receptor for advanced glycation end products (RAGE) in diabetic hearts. Int J Cardiol. 2014; 173(2):236-41. [PubMed: 24630381]

49. De Metrio M, Milazzo V, Rubino M, Cabiati A, Moltrasio M, Marana I, et al. Vitamin D plasma levels and in-hospital and 1-year outcomes in acute coronary syndromes: a prospective study. Medicine (Baltimore). 2015; 94(19):e857. [PubMed: 25984675] 
50. Roy A, Lakshmy R, Tarik M, Tandon N, Reddy KS, Prabhakaran D. Independent association of severe vitamin D deficiency as a risk of acute myocardial infarction in Indians. Indian Heart J. 2015; 67(1):27-32. [PubMed: 25820047]

51. Glueck CJ, Jetty V, Rothschild M, Duhon G, Shah P, Prince M, et al. Associations between Serum 25-hydroxyvitamin D and Lipids, Lipoprotein Cholesterols, and Homocysteine. N Am J Med Sci. 2016; 8(7):284-90. [PubMed: 27583236]

52. Gupta GK, Agrawal T, Rai V, Del Core MG, Hunter WJ 3rd, Agrawal DK. Vitamin D Supplementation Reduces Intimal Hyperplasia. Restenosis following Coronary Intervention in Atherosclerotic Swine. PLoS One. 2016; 11(6):e0156857. [PubMed: 27271180]

53. Satilmis S, Celik O, Biyik I, Ozturk D, Celik K, Akin F, et al. Association between serum vitamin $\mathrm{D}$ levels and subclinical coronary atherosclerosis and plaque burden/composition in young adult population. Bosn J Basic Med Sci. 2015; 15(1):67-72.

54. Tokarz A, Kusnierz-Cabala B, Kuzniewski M, Gacon J, Mazur-Laskowska M, Stepien EL. Seasonal effect of vitamin D deficiency in patients with acute myocardial infarction. Kardiol Pol. 2016

55. Gondim F, Caribe A, Vasconcelos KF, Segundo AD, Bandeira F. Vitamin D Deficiency Is Associated with Severity of Acute Coronary Syndrome in Patients with Type 2 Diabetes and High Rates of Sun Exposure. Clin Med Insights Endocrinol Diabetes. 2016; 9:37-41. [PubMed: 27625577]

56. Eren E, Ellidag HY, Yilmaz A, Aydin O, Yilmaz N. No association between vitamin D levels and inflammation markers in patients with acute coronary syndrome. Adv Med Sci. 2015; 60(1):8993. [PubMed: 25615956]

57. Brondum-Jacobsen P, Benn M, Afzal S, Nordestgaard BG. No evidence that genetically reduced 25-hydroxyvitamin $\mathrm{D}$ is associated with increased risk of ischaemic heart disease or myocardial infarction: a Mendelian randomization study. Int J Epidemiol. 2015; 44(2):651-61. [PubMed: 25981321]

58. Zostautiene I, Jorde R, Schirmer H, Mathiesen EB, Njolstad I, Lochen ML, et al. Genetic Variations in the Vitamin D Receptor Predict Type 2 Diabetes and Myocardial Infarction in a Community-Based Population: The Tromso Study. PLoS One. 2015; 10(12):e0145359. [PubMed: 26699871]

59. Yao T, Ying X, Zhao Y, Yuan A, He Q, Tong H, et al. Vitamin D receptor activation protects against myocardial reperfusion injury through inhibition of apoptosis and modulation of autophagy. Antioxid Redox Signal. 2015; 22(8):633-50. [PubMed: 25365634]

60. Diez ER, Altamirano LB, Garcia IM, Mazzei L, Prado NJ, Fornes MW, et al. Heart remodeling and ischemia-reperfusion arrhythmias linked to myocardial vitamin $d$ receptors deficiency in obstructive nephropathy are reversed by paricalcitol. J Cardiovasc Pharmacol Ther. 2015; 20(2): 211-20. [PubMed: 24924917]

61. Lipson KE, Wong C, Teng Y, Spong S. CTGF is a central mediator of tissue remodeling and fibrosis and its inhibition can reverse the process of fibrosis. Fibrogenesis Tissue Repair. 2012; 5(Suppl 1):S24. [PubMed: 23259531]

62. Biernacka A, Cavalera M, Wang J, Russo I, Shinde A, Kong P, et al. Smad3 Signaling Promotes Fibrosis While Preserving Cardiac and Aortic Geometry in Obese Diabetic Mice. Circ Heart Fail. 2015; 8(4):788-98. [PubMed: 25985794]

63. Qu H, Lin K, Wang H, Wei H, Ji B, Yang Z, et al. 1,25(OH)2 D3 improves cardiac dysfunction, hypertrophy, and fibrosis through PARP1/SIRT1/mTOR-related mechanisms in type 1 diabetes. Mol Nutr Food Res. 2016

64. Meredith A, Boroomand S, Carthy J, Luo Z, McManus B. 1,25 Dihydroxyvitamin D3 Inhibits TGFbeta1-Mediated Primary Human Cardiac Myofibroblast Activation. PLoS One. 2015; 10(6):e0128655. [PubMed: 26061181]

65. Tian Y, Lv G, Yang Y, Zhang Y, Yu R, Zhu J, et al. Effects of vitamin D on renal fibrosis in diabetic nephropathy model rats. Int J Clin Exp Pathol. 2014; 7(6):3028-37. [PubMed: 25031721]

66. Ito I, Waku T, Aoki M, Abe R, Nagai Y, Watanabe T, et al. A nonclassical vitamin D receptor pathway suppresses renal fibrosis. J Clin Invest. 2013; 123(11):4579-94. [PubMed: 24135137] 
67. Wang L, Yuan T, Du G, Zhao Q, Ma L, Zhu J. The impact of 1,25-dihydroxyvitamin D3 on the expression of connective tissue growth factor and transforming growth factor-beta1 in the myocardium of rats with diabetes. Diabetes Res Clin Pract. 2014; 104(2):226-33. [PubMed: 24613393]

68. Saxena A, Chen W, Su Y, Rai V, Uche OU, Li N, et al. IL-1 induces proinflammatory leukocyte infiltration and regulates fibroblast phenotype in the infarcted myocardium. J Immunol. 2013; 191(9):4838-48. [PubMed: 24078695]

69. Hlaing SM, Garcia LA, Contreras JR, Norris KC, Ferrini MG, Artaza JN. 1,25-Vitamin D3 promotes cardiac differentiation through modulation of the WNT signaling pathway. J Mol Endocrinol. 2014; 53(3):303-17. [PubMed: 25139490]

70. Gao L, Cao JT, Liang Y, Zhao YC, Lin XH, Li XC, et al. Calcitriol attenuates cardiac remodeling and dysfunction in a murine model of polycystic ovary syndrome. Endocrine. 2016; 52(2):363-73. [PubMed: 26578366]

71. Panizo S, Barrio-Vazquez S, Naves-Diaz M, Carrillo-Lopez N, Rodriguez I, Fernandez-Vazquez A, et al. Vitamin D receptor activation, left ventricular hypertrophy and myocardial fibrosis. Nephrol Dial Transplant. 2013; 28(11):2735-44. [PubMed: 24013683]

72. Fujii H, Nakai K, Yonekura Y, Kono K, Goto S, Hirata M, et al. The Vitamin D Receptor Activator Maxacalcitol Provides Cardioprotective Effects in Diabetes Mellitus. Cardiovasc Drugs Ther. 2015; 29(6):499-507. [PubMed: 26602563]

73. Mizobuchi M, Ogata H, Yamazaki-Nakazawa A, Hosaka N, Kondo F, Koiwa F, et al. Cardiac effect of vitamin D receptor modulators in uremic rats. J Steroid Biochem Mol Biol. 2016; 163:20-7. [PubMed: 27072785]

74. Meems LM, Brouwers FP, Joosten MM, Lambers Heerspink HJ, de Zeeuw D, Bakker SJ, et al. Plasma calcidiol, calcitriol, and parathyroid hormone and risk of new onset heart failure in a population-based cohort study. ESC Heart Fail. 2016; 3(3):189-97.

75. Schleithoff SS, Zittermann A, Tenderich G, Berthold HK, Stehle P, Koerfer R. Vitamin D supplementation improves cytokine profiles in patients with congestive heart failure: a doubleblind, randomized, placebo-controlled trial. Am J Clin Nutr. 2006; 83(4):754-9. [PubMed: 16600924]

76. Seki K, Sanada S, Kudinova AY, Steinhauser ML, Handa V, Gannon J, et al. Interleukin-33 prevents apoptosis and improves survival after experimental myocardial infarction through ST2 signaling. Circ Heart Fail. 2009; 2(6):684-91. [PubMed: 19919994]

77. Yao HC, Li XY, Han QF, Wang LH, Liu T, Zhou YH, et al. Elevated serum soluble ST2 levels may predict the fatal outcomes in patients with chronic heart failure. Int J Cardiol. 2015; 186:303-4. [PubMed: 25828142]

78. Schierbeck LL, Jensen TS, Bang U, Jensen G, Kober L, Jensen JE. Parathyroid hormone and vitamin D--markers for cardiovascular and all cause mortality in heart failure. Eur J Heart Fail. 2011; 13(6):626-32. [PubMed: 21415099]

79. Pfeffer PE, Chen YH, Woszczek G, Matthews NC, Chevretton E, Gupta A, et al. Vitamin D enhances production of soluble ST2, inhibiting the action of IL-33. J Allergy Clin Immunol. 2015; 135(3):824-7. e3. [PubMed: 25457999]

80. Gruson D, Ferracin B, Ahn SA, Rousseau MF. Soluble ST2, the vitamin D/PTH axis and the heart: New interactions in the air? Int J Cardiol. 2016; 212:292-4. [PubMed: 27057941]

81. Masson S, Barlera S, Colotta F, Magnoli M, Bonelli F, Moro M, et al. A low plasma 1,25(OH)2 vitamin D/PTH (1-84) ratio predicts worsening of renal function in patients with chronic heart failure. Int J Cardiol. 2016; 224:220-5. [PubMed: 27657477]

82. Belen E, Sungur A, Sungur MA. Vitamin D levels predict hospitalization and mortality in patients with heart failure. Scand Cardiovasc J. 2016; 50(1):17-22. [PubMed: 26395845]

83. Gotsman I, Shauer A, Zwas DR, Hellman Y, Keren A, Lotan C, et al. Vitamin D deficiency is a predictor of reduced survival in patients with heart failure; vitamin D supplementation improves outcome. Eur J Heart Fail. 2012; 14(4):357-66. [PubMed: 22308011]

84. Jiang WL, Gu HB, Zhang YF, Xia QQ, Qi J, Chen JC. Vitamin D Supplementation in the Treatment of Chronic Heart Failure: A Meta-analysis of Randomized Controlled Trials. Clin Cardiol. 2016; 39(1):56-61. [PubMed: 26415519] 
85. Robbins J, Petrone AB, Gaziano JM, Djousse L. Dietary vitamin D and risk of heart failure in the Physicians' Health Study. Clin Nutr. 2016; 35(3):650-3. [PubMed: 26077474]

86. Hsia J, Heiss G, Ren H, Allison M, Dolan NC, Greenland P, et al. Calcium/vitamin D supplementation and cardiovascular events. Circulation. 2007; 115(7):846-54. [PubMed: 17309935]

87. Abu El Maaty MA, Hassanein SI, Gad MZ. Genetic variation in vitamin D receptor gene (Fok1:rs2228570) is associated with risk of coronary artery disease. Biomarkers. 2016; 21(1):6872. [PubMed: 26643870]

88. Donneyong MM, Hornung CA, Taylor KC, Baumgartner RN, Myers JA, Eaton CB, et al. Risk of heart failure among postmenopausal women: a secondary analysis of the randomized trial of vitamin D plus calcium of the women's health initiative. Circ Heart Fail. 2015; 8(1):49-56. [PubMed: 25398967]

89. Vaidya A, Sun B, Forman JP, Hopkins PN, Brown NJ, Kolatkar NS, et al. The Fok1 vitamin D receptor gene polymorphism is associated with plasma renin activity in Caucasians. Clin Endocrinol (Oxf). 2011; 74(6):783-90. [PubMed: 21521263]

90. Witte KK, Byrom R, Gierula J, Paton MF, Jamil HA, Lowry JE, et al. Effects of Vitamin D on Cardiac Function in Patients With Chronic HF: The VINDICATE Study. J Am Coll Cardiol. 2016; 67(22):2593-603. [PubMed: 27058906]

91. Schroten NF, Ruifrok WP, Kleijn L, Dokter MM, Sillje HH, Lambers Heerspink HJ, et al. Shortterm vitamin D3 supplementation lowers plasma renin activity in patients with stable chronic heart failure: an open-label, blinded end point, randomized prospective trial (VitD-CHF trial). Am Heart J. 2013; 166(2):357-64. e2. [PubMed: 23895820]

92. Belen E, Aykan AC, Kalaycioglu E, Sungur MA, Sungur A, Cetin M. Low-Level Vitamin D Is Associated with Atrial Fibrillation in Patients with Chronic Heart Failure. Adv Clin Exp Med. 2016; 25(1):51-7. [PubMed: 26935498]

93. Canpolat U, Aytemir K, Hazirolan T, Ozer N, Oto A. Relationship between vitamin D level and left atrial fibrosis in patients with lone paroxysmal atrial fibrillation undergoing cryoballoon-based catheter ablation. J Cardiol. 2017; 69(1):16-23. [PubMed: 27554047]

94. Emren SV, Aldemir M, Ada F. Does Deficiency of Vitamin D Increase New Onset Atrial Fibrillation after Coronary Artery Bypass Grafting Surgery? Heart Surg Forum. 2016; 19(4):E1804. [PubMed: 27585197]

95. Li YC, Qiao G, Uskokovic M, Xiang W, Zheng W, Kong J. Vitamin D: a negative endocrine regulator of the renin-angiotensin system and blood pressure. J Steroid Biochem Mol Biol. 2004; 89-90(1-5):387-92.

96. Cerit L, Kemal H, Gulsen K, Ozcem B, Cerit Z, Duygu H. Relationship between Vitamin D and the development of atrial fibrillation after on-pump coronary artery bypass graft surgery. Cardiovasc $\mathrm{J}$ Afr. 2016; 27:1-4. [PubMed: 27942694]

97. Alonso A, Misialek JR, Michos ED, Eckfeldt J, Selvin E, Soliman EZ, et al. Serum 25hydroxyvitamin D and the incidence of atrial fibrillation: the Atherosclerosis Risk in Communities (ARIC) study. Europace. 2016; 18(8):1143-9. [PubMed: 26847078]

98. Pelham CJ, Drews EM, Agrawal DK. Vitamin D controls resistance artery function through regulation of perivascular adipose tissue hypoxia and inflammation. J Mol Cell Cardiol. 2016; 98:1-10. [PubMed: 27374117]

99. Lin LM, Peng F, Liu YP, Chai DJ, Ning RB, Xu CS, et al. Coadministration of VDR and RXR agonists synergistically alleviates atherosclerosis through inhibition of oxidative stress: An in vivo and in vitro study. Atherosclerosis. 2016; 251:273-81. [PubMed: 27428295]

100. Dziedzic EA, Przychodzen S, Dabrowski M. The effects of vitamin D on severity of coronary artery atherosclerosis and lipid profile of cardiac patients. Arch Med Sci. 2016; 12(6):1199-206. [PubMed: 27904508]

101. Michos ED, Selvin E, Misialek JR, McEvoy JW, Ndumele CE, Folsom AR, et al. 25Hydroxyvitamin D Levels and Markers of Subclinical Myocardial Damage and Wall Stress: The Atherosclerosis Risk in Communities Study. J Am Heart Assoc. 2016; 5(11)

102. Stakisaitis D, Lesauskaite V, Girdauskaite M, Janulionis E, Ulys A, Benetis R. Investigation of Vitamin D-Binding Protein Polymorphism Impact on Coronary Artery Disease and Relationship 
with Longevity: Own Data and a Review. Int J Endocrinol. 2016; 2016:8347379. [PubMed: 27143969]

103. Ng YM, Lim SK, Kang PS, Kadir KA, Tai MS. Association between serum 25-hydroxyvitamin D levels and carotid atherosclerosis in chronic kidney disease patients. BMC Nephrol. 2016; 17(1): 151. [PubMed: 27756244]

104. Rai V, Rao VH, Shao Z, Agrawal DK. Dendritic Cells Expressing Triggering Receptor Expressed on Myeloid Cells-1 Correlate with Plaque Stability in Symptomatic and Asymptomatic Patients with Carotid Stenosis. PLoS One. 2016; 11(5):e0154802. [PubMed: 27148736]

105. Rao VH, Rai V, Stoupa S, Subramanian S, Agrawal DK. Tumor necrosis factor-alpha regulates triggering receptor expressed on myeloid cells-1-dependent matrix metalloproteinases in the carotid plaques of symptomatic patients with carotid stenosis. Atherosclerosis. 2016; 248:160-9. [PubMed: 27017522]

106. Carbone F, Satta N, Burger F, Roth A, Lenglet S, Pagano S, et al. Vitamin D receptor is expressed within human carotid plaques and correlates with pro-inflammatory M1 macrophages. Vascul Pharmacol. 2016; 85:57-65. [PubMed: 27555526]

107. Yin K, You Y, Swier V, Tang L, Radwan MM, Pandya AN, et al. Vitamin D Protects Against Atherosclerosis via Regulation of Cholesterol Efflux and Macrophage Polarization in Hypercholesterolemic Swine. Arterioscler Thromb Vasc Biol. 2015; 35(11):2432-42. [PubMed: 26381871]

108. Haas MJ, Jafri M, Wehmeier KR, Onstead-Haas LM, Mooradian AD. Inhibition of endoplasmic reticulum stress and oxidative stress by vitamin D in endothelial cells. Free Radic Biol Med. 2016; 99:1-10. [PubMed: 27458123]

109. Xiang W, Hu ZL, He XJ, Dang XQ. Intravenous transfusion of endothelial progenitor cells that overexpress vitamin $\mathrm{D}$ receptor inhibits atherosclerosis in apoE-deficient mice. Biomed Pharmacother. 2016; 84:1233-42. [PubMed: 27810779]

110. Lee S, Ahuja V, Masaki K, Evans RW, Barinas-Mitchell EJ, Ueshima H, et al. A Significant Positive Association of Vitamin D Deficiency with Coronary Artery Calcification among Middleaged Men: For the ERA JUMP Study. J Am Coll Nutr. 2016; 35(7):614-20. [PubMed: 27315115]

111. Dogan Y, Sarli B, Baktir AO, Kurtul S, Akpek M, Sahin O, et al. 25-Hydroxy-vitamin D level may predict presence of coronary collaterals in patients with chronic coronary total occlusion. Postepy Kardiol Interwencyjnej. 2015; 11(3):191-6. [PubMed: 26677358]

112. Martinez-Moreno JM, Herencia C, Montes de Oca A, Munoz-Castaneda JR, Rodriguez-Ortiz ME, Diaz-Tocados JM, et al. Vitamin D modulates tissue factor and protease-activated receptor 2 expression in vascular smooth muscle cells. FASEB J. 2016; 30(3):1367-76. [PubMed: 26700731]

113. Sagarad SV, Sukhani N, Machanur B, Patil S. Effect of Vitamin D on Anginal Episodes in Vitamin D Deficient Patients with Chronic Stable Angina on Medical Management. J Clin Diagn Res. 2016; 10(8):OC24-6.

114. Wong YY, Flicker L, Yeap BB, McCaul KA, Hankey GJ, Norman PE. Is hypovitaminosis D associated with abdominal aortic aneurysm, and is there a dose-response relationship? Eur J Vasc Endovasc Surg. 2013; 45(6):657-64. [PubMed: 23602862]

115. Martorell S, Hueso L, Gonzalez-Navarro H, Collado A, Sanz MJ, Piqueras L. Vitamin D Receptor Activation Reduces Angiotensin-II-Induced Dissecting Abdominal Aortic Aneurysm in Apolipoprotein E-Knockout Mice. Arterioscler Thromb Vasc Biol. 2016; 36(8):1587-97. [PubMed: 27283745]

116. Nieuwland AJ, Kokje VB, Koning OH, Hamming JF, Szuhai K, Claas FH, et al. Activation of the vitamin D receptor selectively interferes with calcineurin-mediated inflammation: a clinical evaluation in the abdominal aortic aneurysm. Lab Invest. 2016; 96(7):784-90. [PubMed: 27239732]

117. Chen S, Sun Y, Agrawal DK. Vitamin D deficiency and essential hypertension. J Am Soc Hypertens. 2015; 9(11):885-901. [PubMed: 26419755] 
118. Yilmaz S, Sen F, Ozeke O, Temizhan A, Topaloglu S, Aras D, et al. The relationship between vitamin D levels and nondipper hypertension. Blood Press Monit. 2015; 20(6):330-4. [PubMed: 26241293]

119. Zagami RM, Di Pino A, Urbano F, Piro S, Purrello F, Rabuazzo AM. Low circulating vitamin D levels are associated with increased arterial stiffness in prediabetic subjects identified according to HbA1c. Atherosclerosis. 2015; 243(2):395-401. [PubMed: 26520892]

120. Kang JY, Kim MK, Jung S, Shin J, Choi BY. The cross-sectional relationships of dietary and serum vitamin D with cardiometabolic risk factors: Metabolic components, subclinical atherosclerosis, and arterial stiffness. Nutrition. 2016; 32(10):1048-56. e1. [PubMed: 27179408]

121. Kassi E, Adamopoulos C, Basdra EK, Papavassiliou AG. Role of vitamin D in atherosclerosis. Circulation. 2013; 128(23):2517-31. [PubMed: 24297817]

122. Belkaid Y, Hand TW. Role of the microbiota in immunity and inflammation. Cell. 2014; 157(1): 121-41. [PubMed: 24679531]

123. Wu HJ, Wu E. The role of gut microbiota in immune homeostasis and autoimmunity. Gut Microbes. 2012; 3(1):4-14. [PubMed: 22356853]

124. Gominak SC. Vitamin D deficiency changes the intestinal microbiome reducing B vitamin production in the gut. The resulting lack of pantothenic acid adversely affects the immune system, producing a "pro-inflammatory" state associated with atherosclerosis and autoimmunity. Med Hypotheses. 2016; 94:103-7. [PubMed: 27515213]

125. Henry HL. Regulation of vitamin D metabolism. Best Pract Res Clin Endocrinol Metab. 2011; 25(4):531-41. [PubMed: 21872796]

126. Ding HY, Ma HX. Significant roles of anti-aging protein klotho and fibroblast growth factor 23 in cardiovascular disease. J Geriatr Cardiol. 2015; 12(4):439-47. [PubMed: 26347327]

127. Moe SM, Chertow GM, Parfrey PS, Kubo Y, Block GA, Correa-Rotter R, et al. Cinacalcet, Fibroblast Growth Factor-23, and Cardiovascular Disease in Hemodialysis: The Evaluation of Cinacalcet $\mathrm{HCl}$ Therapy to Lower Cardiovascular Events (EVOLVE) Trial. Circulation. 2015; 132(1):27-39. [PubMed: 26059012]

128. Andrukhova O, Slavic S, Odorfer KI, Erben RG. Experimental Myocardial Infarction Upregulates Circulating Fibroblast Growth Factor-23. J Bone Miner Res. 2015; 30(10):1831-9. [PubMed: 25858796]

129. Mathew JS, Sachs MC, Katz R, Patton KK, Heckbert SR, Hoofnagle AN, et al. Fibroblast growth factor-23 and incident atrial fibrillation: the Multi-Ethnic Study of Atherosclerosis (MESA) and the Cardiovascular Health Study (CHS). Circulation. 2014; 130(4):298-307. [PubMed: 24920722]

130. Xie J, Wu YL, Huang CL. Deficiency of Soluble alpha-Klotho as an Independent Cause of Uremic Cardiomyopathy. Vitam Horm. 2016; 101:311-30. [PubMed: 27125747]

131. Bansal N, Zelnick L, Robinson-Cohen C, Hoofnagle AN, Ix JH, Lima JA, et al. Serum parathyroid hormone and 25-hydroxyvitamin D concentrations and risk of incident heart failure: the Multi-Ethnic Study of Atherosclerosis. J Am Heart Assoc. 2014; 3(6):e001278. [PubMed: 25468653]

132. Kopecky SL, Bauer DC, Gulati M, Nieves JW, Singer AJ, Toth PP, et al. Lack of Evidence Linking Calcium With or Without Vitamin D Supplementation to Cardiovascular Disease in Generally Healthy Adults: A Clinical Guideline From the National Osteoporosis Foundation and the American Society for Preventive Cardiology. Ann Intern Med. 2016; 165(12):867-868. [PubMed: 27776362]

133. Levy BI. Can angiotensin II type 2 receptors have deleterious effects in cardiovascular disease? Implications for therapeutic blockade of the renin-angiotensin system. Circulation. 2004; 109(1): 8-13. [PubMed: 14707017]

134. Singh KD, Karnik SS. Angiotensin Receptors: Structure, Function, Signaling and Clinical Applications. J Cell Signal. 2016; 1(2)

135. Chow BS, Koulis C, Krishnaswamy P, Steckelings UM, Unger T, Cooper ME, et al. The angiotensin II type 2 receptor agonist Compound 21 is protective in experimental diabetesassociated atherosclerosis. Diabetologia. 2016; 59(8):1778-90. [PubMed: 27168137] 
136. Yoshida T, Delafontaine P. An Intronic Enhancer Element Regulates Angiotensin II Type 2 Receptor Expression during Satellite Cell Differentiation, and Its Activity Is Suppressed in Congestive Heart Failure. J Biol Chem. 2016; 291(49):25578-25590. [PubMed: 27756842]

137. Michos ED, Lutsey PL. 25-hydroxyvitamin D Levels and Coronary Heart Disease Risk Reclassification in Hypertension--Is it worth the "hype"? Atherosclerosis. 2016; 245:237-9. [PubMed: 26725039]

138. Rai V, Agrawal DK. Role of risk stratification and genetics in sudden cardiac death. Can J Physiol Pharmacol. 2016:1-14.

139. Timms PM, Mannan N, Hitman GA, Noonan K, Mills PG, Syndercombe-Court D, et al. Circulating MMP9, vitamin D and variation in the TIMP-1 response with VDR genotype: mechanisms for inflammatory damage in chronic disorders? QJM. 2002; 95(12):787-96. [PubMed: 12454321]

140. Van den Berghe G, Van Roosbroeck D, Vanhove P, Wouters PJ, De Pourcq L, Bouillon R. Bone turnover in prolonged critical illness: effect of vitamin D. J Clin Endocrinol Metab. 2003; 88(10): 4623-32. [PubMed: 14557432]

141. Teng M, Wolf M, Ofsthun MN, Lazarus JM, Hernan MA, Camargo CA Jr, Thadhani R. Activated injectable vitamin D and hemodialysis survival: a historical cohort study. J Am Soc Nephrol. 2005; 16(4):1115-25. [PubMed: 15728786] 


\section{Key points}

- Vitamin D deficiency is associated with cardiovascular diseases, including coronary artery disease, myocardial infarction, cardiac failure and fibrosis, cardiomyopathy, atherosclerosis, hypertension, and peripheral arterial disease.

- Increased inflammation in diabetes and/or obesity lowers circulating vitamin D levels, thereby increasing the prevalence for cardiovascular diseases.

- Vitamin D supplementation attenuates inflammation and pro-inflammatory cytokines and thus may play a therapeutic role in the treatment of cardiovascular diseases.

- Cardiomyopathy in hypocalcemic patients is reversible with vitamin D supplementation.

- Vitamin D supplementation attenuates atherosclerosis and plaque formation. 


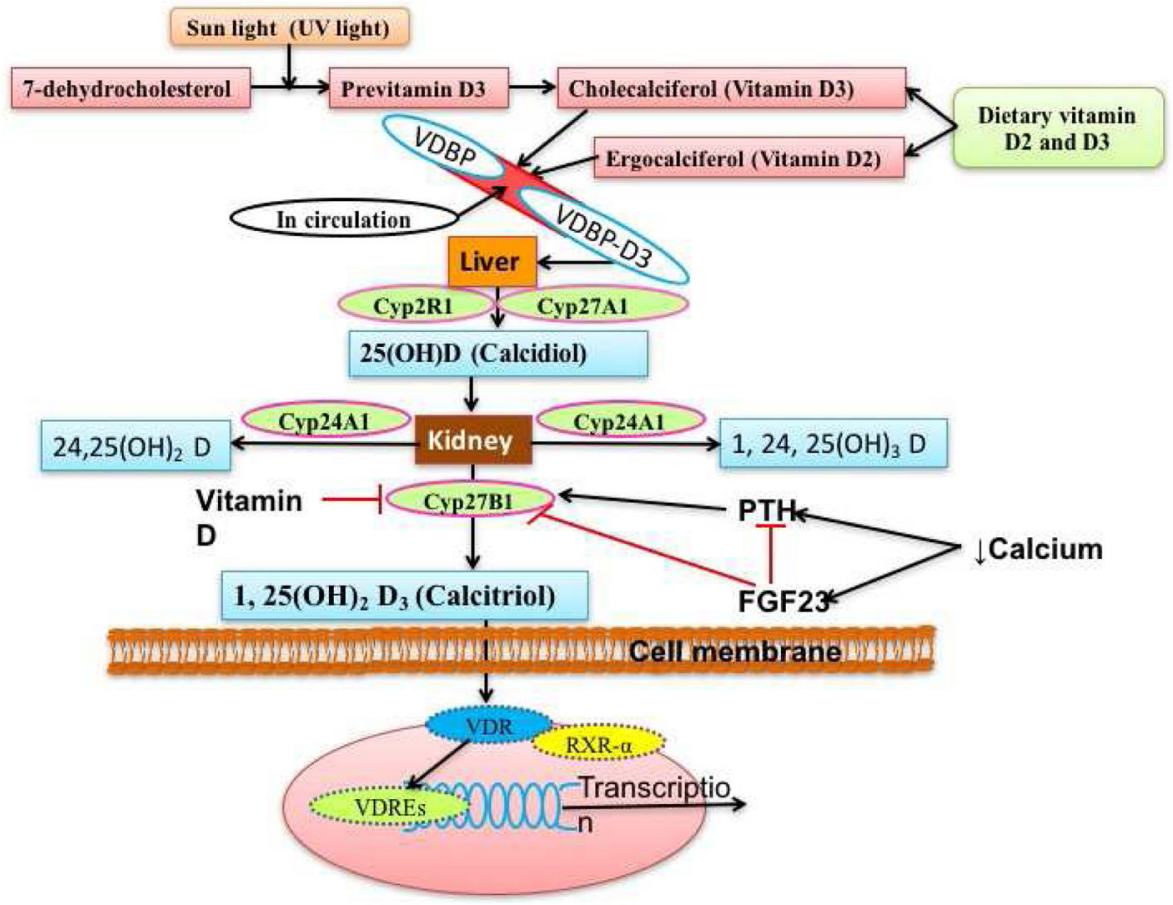

Figure 1. Schematic representation for synthesis and regulation of vitamin $D$

Dietary vitamin D (vitamin D) and pro-vitamin D synthesized in skin under UV light reaches the liver via the blood stream after binding with vitamin D binding protein (VDBP). Hydroxylation of vitamin D mainly with Cyp2R1 (vitamin D 25 hydroxylase) results in the formation of calcidiol $(25(\mathrm{OH}) \mathrm{D})$ which is further hydroxylated with Cyp27B1 (1 ahydroxylase) in the kidney to form calcitriol $\left(1,25(\mathrm{OH})_{2} \mathrm{D}_{3}\right)$-the biologically active form of vitamin D. The activity of Cyp27B1 is regulated by the plasma levels of calcium, phosphate, parathyroid hormone (PTH), fibroblast growth factor-23 (FGF23) and $1,25(\mathrm{OH})_{2} \mathrm{D}_{3}$ itself. RXRa-retinoid X receptor- $a$, VDR-vitamin D receptor, VDRE-vitamin D response elements. 


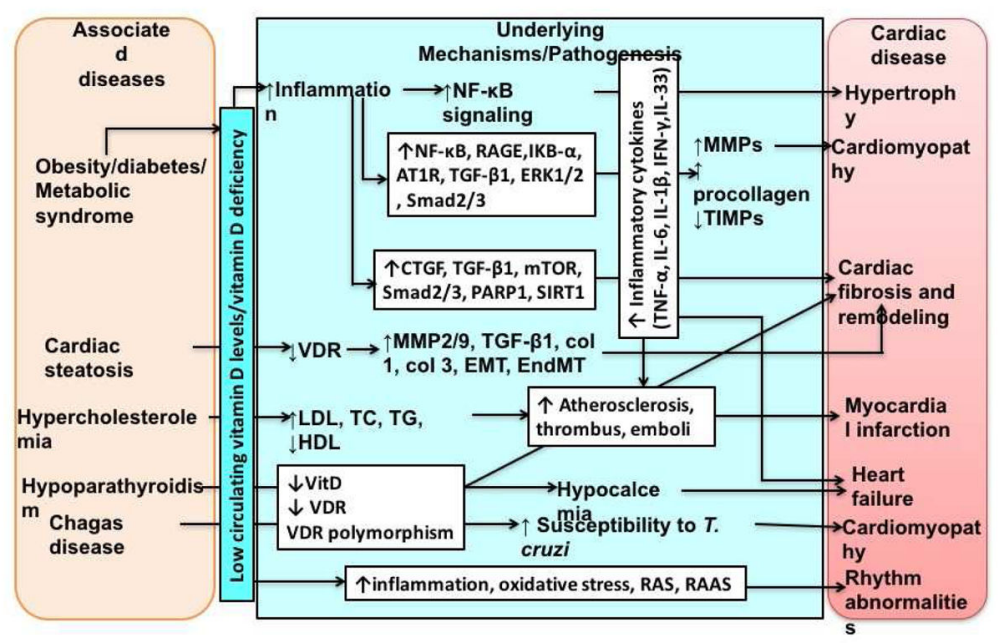

Figure 2. Role of vitamin $D$ deficiency in the pathogenesis of cardiovascular diseases Vitamin D (vitamin D) deficiency is associated with many diseases such as diabetes, obesity, metabolic syndrome, hypercholesterolemia, and hypoparathyroidism, and CVD (cardiovascular disease/s). Vitamin D deficiency results in increased inflammation, increased expression of inflammatory cytokines, and decreased expression and activity of VDR (vitamin D receptor). This results in enhanced signaling of downstream inflammatory signaling cascades leading to collagen loss, fibrosis, increased oxidative stress, increased inflammation, increased sensitivity to infections, and decreased protective mechanisms. The cumulative effect of this results in various CVD such as cardiomyopathy, hypertrophy, myocardial infarction, heart failure, cardiac fibrosis, and rhythm abnormalities. Hence, vitamin D supplementation might decrease these mediators and attenuate the progression and development of CVD. AT1R- angiotensin II type 1 receptor, CTGF- connective tissue growth factor, col 1-collagen 1, col 3- collagen 3, EMT-epithelial- myofibroblast transformation, EndMT-endothelial myofibroblast transformation, ERK1/2- protein-serine/ threonine kinases, HDL- high-density lipoprotein, IKBa-a subunit of inhibitor of $\kappa \mathrm{B}$, IL-6 - interleukin-6, IL-1 $\beta$ - interleukin-1 beta, IL-33 - interleukin-33, IFN- $\gamma$-interferongamma, LDL-low-density lipoprotein, MMPs - matrix metalloproteinases, mTORmechanistic target of rapamycin, NF- $\kappa$ B- nuclear-factor kappa beta, PARP1- poly [ADPribose] polymerase 1, RAGEreceptor for advanced glycation end products, RAS-reninangiotensin system, RAAS- renin-angiotensin-aldosterone system, SIRT1-sirtuin1, SMAD2/3 - Sma- and Mad-Related Protein 2/3, TG- triglycerides, TCtotal cholesterol, TIMPs- tissue inhibitors of metalloproteinases, TNF-a-tumor necrosis factor-alpha, TGF$\beta 1$ - transforming growth factor-beta 1, VDR-vitamin D receptor, vitamin D-vitamin D 


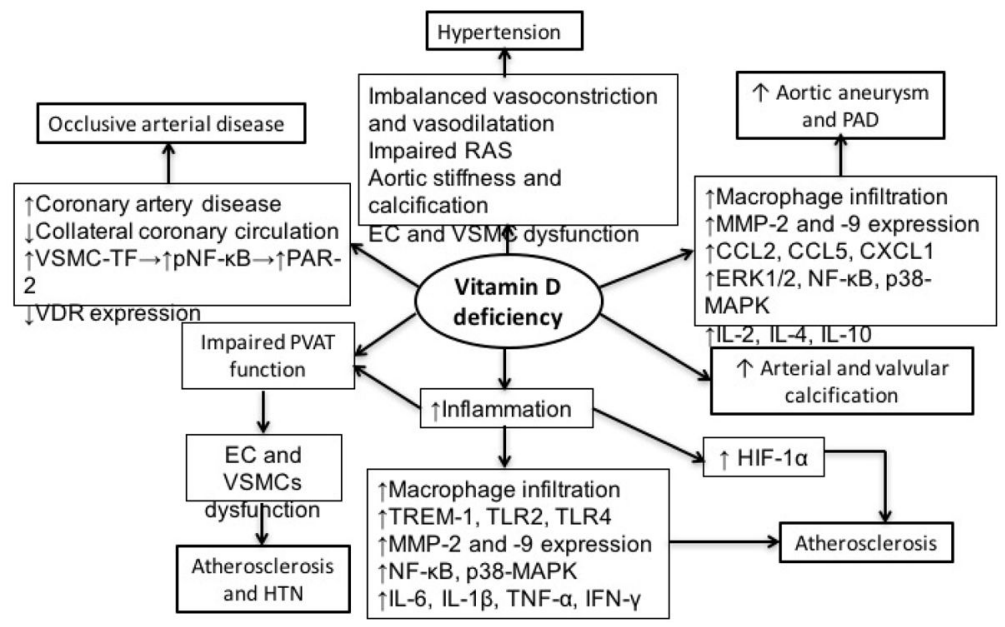

Figure 3. Vitamin D deficiency and development of vascular diseases

Vitamin D deficiency is associated with increased inflammation, increased expression of inflammatory cytokines, endothelial cell and vascular smooth muscle cells dysfunction, and decreased expression and activity of VDR. This enhances and aids in the development of vascular diseases such as atherosclerosis, aneurysms, calcification, stiffness, and hypertension. Since vitamin D deficiency is associated with the pathogenesis of development and progression of vascular diseases, vitamin D supplementation might help in attenuating the development and progression of these vascular diseases. CCL2- chemokine (C-C motif) ligand 2, CCL5- chemokine (C-C motif) ligand 5, CXCL1- Chemokine (C-X-C Motif) Ligand 1, EC- endothelial cells, ERK1/2- protein-serine/threonine kinases, HIF-1 ahypoxia-induced factor-1 alpha, HTN- hypertension, IL-2,IL-4, IL-6, IL-10 - interleukin-2, interleukin-4, interluekin-6, interleukin-10, IL-1 $\beta$ - interleukin-1 beta, IFN- $\gamma$-interferongamma, MMP2 and MMP9 - matrix metalloproteinases 2 and 9, p38MAPKp38 mitogenactivated protein kinases, pNF- $\kappa$ B- phosphorylated nuclear-factor kappa beta, PAR-2protease-activated protein 2, PVAT- perivascular adipose tissue, RAS- renin-angiotensin system, TREM-1-triggering receptor expressed on myeloid cells 1, TLR2- toll-like receptor 2, TLR4- toll-like receptor 4, TNF-a-tumor necrosis factor-alpha, VSMC-TF- vascular smooth muscle cells-tissue factor, VDR-vitamin D receptor, vitamin D-vitamin D. 


\section{Table 1}

Cardioprotective role of vitamin D supplementation in clinical studies: Vitamin D supplementation with or without calcium with improvement in clinical symptoms and cardiac morphology and function in these clinical studies suggest cardioprotective role of vitamin D.

\begin{tabular}{|c|c|c|c|c|}
\hline & Disease & Intervention & Mechanism & Beneficial effect \\
\hline \multirow[t]{8}{*}{ Human } & DCM with HF [34] & $\begin{array}{l}\text { vitamin D +calcium } \\
\text { supplementation x } 1 \\
\text { week }\end{array}$ & NA & $\begin{array}{l}\text { Rapid improvement in cardiac } \\
\text { morphology and function }\end{array}$ \\
\hline & DCM [35] & $\begin{array}{l}\text { vitamin } D+\text { calcium } \\
\text { supplementation } x \\
\text { few days }\end{array}$ & NA & $\begin{array}{l}\text { Rapid improvement in clinical } \\
\text { symptoms and cardiac function }\end{array}$ \\
\hline & DCM with HF [37] & $\begin{array}{l}\text { Oral calcium and } \\
\text { calcitriol in doses of } \\
3 \mathrm{~g} / \mathrm{d} \text { and } 1.5 \mu \mathrm{g} / \mathrm{d} \times 2 \\
\text { months, } 47 \mathrm{yr} \text { old pt. }\end{array}$ & Treated secondary hyperparathyroidism & $\begin{array}{l}\text { Improvement in clinical } \\
\text { symptoms and cardiac function }\end{array}$ \\
\hline & DCM with HF [37] & $\begin{array}{l}10 \% \text { calcium } \\
\text { gluconate (i.v } 2 \\
\mathrm{~mL} / \mathrm{kg} \times 30 \text { min. }+80 \\
\mathrm{mg} / \mathrm{kg} / \mathrm{d} \times 48 \text { hours) } \\
\text { Oral calcium } \\
\text { carbonate } 100 \\
\mathrm{mg} / \mathrm{kg} / \mathrm{d}+\text { calcitriol } \\
0.125 \mu \mathrm{\mu g} / \mathrm{d} \mathrm{x} 3 \\
\mathrm{months}, 2 \text { months old } \\
\text { pt. }\end{array}$ & $\begin{array}{l}\text { Treatment of Vitamin D deficiency and } \\
\text { hypocalcemia }\end{array}$ & $\begin{array}{l}\text { Improvement in clinical } \\
\text { symptoms and cardiac function }\end{array}$ \\
\hline & Chronic HF [90] & $\begin{array}{l}100 \mu \mathrm{g} \text { daily Vitamin } \\
\mathrm{D}_{3} \text { supplementation } \mathrm{x} \\
1 \text { year, } 229 \text { pts. }\end{array}$ & NA & $\begin{array}{l}\text { Significant improvement in } \\
\text { cardiac function with reversal of } \\
\text { LV remodelling }\end{array}$ \\
\hline & Chronic HF [91] & $\begin{array}{l}2,000 \text { IU oral Vitamin } \\
\mathrm{D}_{3} \text { daily x } 6 \text { weeks, } \\
101 \text { pts. }\end{array}$ & NA & $\begin{array}{l}\text { Larger decrease in plasma renin } \\
\text { concentration }\end{array}$ \\
\hline & Anginal episodes [113] & $\begin{array}{l}\text { Vitamin D } \\
\text { supplementation } \\
\text { (60000 IU/week x } \\
\text { 8weeks) to } 20 \text { pts. }\end{array}$ & NA & $\begin{array}{l}\text { Significant } 20 \% \text { reduction in } \\
\text { anginal episodes and } 17.24 \% \\
\text { reduction in use of sub-lingual } \\
\text { nitrates }\end{array}$ \\
\hline & AAA [116] & $\begin{array}{l}\text { Paricalcitol } 1 \mu \mathrm{g} \text { daily } \\
\text { x } 2-4 \text { weeks }\end{array}$ & VDR activation & $\begin{array}{l}\text { Decreased calcineurin-mediated } \\
\text { inflammation in the arterial wall }\end{array}$ \\
\hline \multirow[t]{2}{*}{ In-vitro } & Arterial thrombosis [112] & $\begin{array}{l}\text { Calcitriol }\left(10^{-8} \mathrm{M}\right) \\
\text { and paricalcitol } \\
\left(3 \times 10^{-8} \mathrm{M}\right) \text { to } \\
\text { HAVSMCs }\end{array}$ & $\begin{array}{l}\text { reduce expression of TF induced by } \\
\text { TNF- } a \text { in HAVSMCs }\end{array}$ & Reduced prothrombotic state \\
\hline & Cardiac fibrosis [64] & $\begin{array}{l}\text { Calcitriol- } 1 \mu \mathrm{M} \text { to } \\
\text { HCF-av } 24-48 \mathrm{hr}\end{array}$ & $\begin{array}{l}\text { Inhibition of TGF } \beta 1 \text {-mediated cell } \\
\text { contraction }\end{array}$ & $\begin{array}{l}\text { Prevention of biochemical and } \\
\text { functional pro-fibrotic changes } \\
\text { in human primary cardiac } \\
\text { fibroblasts }\end{array}$ \\
\hline
\end{tabular}

AAA- Abdominal aortic aneurysm, DCM-dilated cardiomyopathy, HAVSMCs- human aortic smooth muscle cells, HCF-av- primary human adult ventricular cardiac fibroblasts, HE-heart failure, LV- left ventricle, NA- not available/not mentioned, pts.- patient(s), TNF-a-tumor necrosis factoralpha, TGF- $\beta 1$-transforming growth factor-beta 1, VSMCs-TF- vascular smooth muscle cells -tissue factor, VDR-vitamin D receptor, vitamin Dvitamin $\mathrm{D}$ 